\title{
ANALISIS KOMPETENSI TECHNOLOGICAL PEDAGOGICAL AND CONTENT KNOWLEDGE PADA GURU SEKOLAH VOKASI KEMARITIMAN
}

\author{
Basith Rahmatullah*, Henry Praherdhiono, Agus Wedi \\ Teknologi Pembelajaran, Pascasarjana, Universitas Negeri Malang
}

\section{Edcomtech}

Jurnal Kajian Teknolog
Pendidikan
Volume 6, No 2, Oktober 2021
186-198
DOI: 10.17977/um039v6i12021p186

Submitted 04-05-2020

Accepted 24-04-2021

\section{Corresponding Author*}

Basith Rahmatullah

Universitas Negeri Malang

Jl. Semarang No.5, Sumbersari,

Kec. Lowokwaru, Kota Malang,

Jawa Timur 65145, Indonesia

Email: basithr354@gmail.com

\begin{abstract}
Abstrak
Menganalisis dan menginvestigasi pemahaman dan keterampilan Technological Pedagogical and Content Knowledge guru sekolah vokasi kemaritiman adalah tujuan dari riset ini. Teknik penelitian yang digunakan pada penelitian ini adalah pendekatan deskriptif dengan pendekatan kuantitatif. Teknik penghimpunan data yang dilakukan adalah dengan teknik penyebaran angket dengan mengambil sampel secara acak sebanyak 12 guru atau sebesar $60 \%$ dari total 20 guru pada 8 sekolah vokasi bidang kemaritiman. Hasil riset studi analisis menginterpretasikan bahwa semua bagian kemampuan Technological Pedagogical and Content Knowledge (TPACK) pada guru sekolah vokasi bidang kemaritiman menghasilkan kategori ke dalam kelompok baik dengan nilai rata-rata 3.00. Namun ditemukan juga hasil analisis dari dua bagian TPACK yang masih dalam kategori cukup sehingga memerlukan studi dan penelitian lanjut untuk meningkatkan seluruh bagian TPACK ke dalam kategori baik.
\end{abstract}

Kata Kunci: TPACK; Guru SMK; Kemaritiman

\begin{abstract}
Analyzing and investigating Technological Pedagogical and Content Knowledge understanding and skills of maritime vocational school teachers is the aim of this research. The research technique used in this study is a descriptive approach with a quantitative approach. The data collection technique used was a questionnaire distribution technique by taking a random sample of 12 teachers or $60 \%$ of a total of 20 teachers in 8 maritime vocational schools. The results of the analytical study research interpret that all of the Technological Pedagogical and Content Knowledge (TPACK) abilities in maritime vocational school teachers produce categories into good groups with an average grade of 3.00 . However, it was also found that the results of the analysis of the two TPACK sections were still in the sufficient category so that further studies and research were needed to improve all of the TPACK sections into good categories.
\end{abstract}

Keywords: TPACK; Vocational Teacher; Maritime affairs 


\section{LATAR BELAKANG}

Salah satu elemen yang dapat meningkatkan prestasi belajar peserta didik adalah kehadiran seorang guru. Guru merupakan figur penentu yang paling rutin untuk berkomunikasi dan berinteraksi langsung dengan peserta didik daripada dengan warga sekolah yang lainnya. Guru memiliki kewajiban dalam perencanaan kegiatan belajar mengajar, menerapkan dan melakukan kegiatan belajar mengajar, melakukan pendampingan, mengevaluasi prestasi belajar peserta didik, melakukan penelitian pengkajian kegiatan belajar mengajar serta mampu menjalin komunikasi dengan masyarakat terutama orang tua peserta didik (Sagala, 2009).

Seorang guru adalah suatu tugas dan profesi yang membutuhkan kemampuan, keterampilan dan kompetensi yang harus selalu diterapkan dalam pelaksanaan tugas tersebut. Guru profesional seharusnya memiliki kompetensi pendidikan dan pengajaran. Keterampilan dan kompetensi mengajar harus dimiliki oleh seorang guru. Mengajar adalah suatu metode yang kompleks, sebab mengajar bukan hanya sekedar memberikan materi, informasi ataupun ide dari guru ke peserta didik, melainkan melingkupi berbagai proses kegiatan yang harus dilaksanakan. Dalam pemikiran konstruktivisme mengajar adalah suatu proses yang mengharuskan peserta didik membentuk sendiri pengetahuannya (Kaufman, 2003).

Oleh karena itu, tugas dan tanggung jawab guru adalah mengakomodasi peserta didik agar dapat membangun pengetahuannya dan memperoleh pengajaran yang berguna di kehidupan sehari-hari. Hal tersebut memudahkan guru yang dituntut untuk mampu menguasai isi materi pelajaran dan ilmu pedagogi (ilmu mengajar). Sebagaimana disampaikan dalam perundang-undangan terkait guru dan dosen pada No.14 tahun 2005 memaparkan guru harus mempunyai empat keterampilan, di antaranya adalah keterampilan pedagogi dan keterampilan professional (Indonesia, 2005). Dalam undangundang tersebut dijelaskan yang dimaksud dengan keterampilan pedagogi adalah kapasitas dan keterampilan guru dalam merencanakan, melaksanakan dan menilai hasil pembelajaran serta mempelajari keunikan peserta didik, Sedangkan kompetensi profesional adalah kemampuan guru dalam menguasai isi materi pelajaran. Untuk meningkatkan kemampuan professional atau content knowledge, riwayat pendidikan sangatlah penting, selain itu guru tidak cukup hanya bergantung pada buku teks saja, namun perlu didukung dengan memperbarui informasi terkini disiplin ilmu terkait yang dipublikasikan pada seminar-seminar maupun jurnal penelitian yang telah diterbitkan (Arbianto et al., 2019).

Sekolah vokasi atau sekolah menengah kejuruan (SMK) bidang kemaritiman dibagi menjadi 10 kompetensi keahlian, salah satunya SMK Teknika Kapal Penangkap Ikan. SMK Teknika Kapal Penangkap Ikan memiliki struktur kompetensi sebagai operator peralatan mesin kapal penangkap ikan, teknisi peralatan dan mesin guna pengoperasian kapal untuk memperlancar proses operasi penangkapan ikan. Peserta didik SMK Jurusan Teknika Kapal Penangkap Ikan harus mampu memahami, mendeskripsikan, merawat dan mengoperasikan mesin-mesin kapal penangkap ikan. Dengan demikian perlunya sosok seorang guru yang mampu mengarahkan dan memfasilitasi para peserta didik SMK jurusan teknika kapal penangkap ikan agar berhasil dalam mencapai tujuan pembelajaran dan standar kompetensi lulusan yang telah ditetapkan.

Seorang guru SMK teknika kapal penangkap ikan sudah sepatutnya memiliki pengetahuan dan kompetensi terkait materi teknika kapal penangkap ikan, dan mengajarkan materi tersebut kepada peserta didik. Untuk menguasai cara dalam kegiatan yang berlangsung dalam pelaksanaan pembelajaran dan mengasosiasikan dengan 
cara apa dampak pemahaman dan keterampilan guru dalam kegiatan belajar mengajar. Shulman (1987) menawarkan suatu bingkai kerja (framework) pemahaman dan kompetensi guru yang disebut dengan sebutan Pedagogical Content Knowledge atau dikenal dengan istilah PCK. PCK adalah kombinasi bagian antar pemahaman terkait disiplin ilmu atau konten pembelajaran (content knowledge/CK) dengan kemampuan pengetahuan ilmu mengajar (pedagogical knowledge/PK). PCK merupakan suatu ide yang hadir dari kepercayaan jika pengajaran mengharuskan lebih dari penyampaian pemahaman terkait disiplin ilmu konten pembelajaran kepada peserta didik dan peserta didik memahami isi pembelajaran bukan hanya menerima dan meresapi sebuah keterangan ataupun informasi yang didapatkan melainkan dengan cara apa mengimplementasikan informasi tersebut. Pedagogical Content Knowledge merupakan pemahaman guru yang diselaraskan secara berkesinambungan melewati suatu peristiwa maupun tindakan terkait dengan cara apa mengajarkan isi materi khusus dengan metode tertentu sehingga daya paham peserta didik dapat meningkat (Loughran et al., 2012).

Penelitian dari Ruhrig \& Höttecke (2015) menjelaskan bahwa guru yang profesional bukan semata-mata harus memahami dan memiliki pengetahuan disiplin ilmu atau konten pembelajaran melainkan juga harus memiliki kemampuan mengimplementasikan strategi dalam menyampaikan isi materi pembelajaran. PCK sangat penting bagi seorang guru, Ball et al. (2008) juga menjelaskan bahwa PCK dapat membingkai pengetahuan dan kompetensi guru dengan memusatkan kepada peranan konten dalam pengajaran.

Pembelajaran pada era saat ini guru dituntut untuk menyisipkan kemampuan abad 21 yang mengharuskan adanya pelibatan kemampuan dalam berkomunikasi dan kerjasama serta pemanfaatan teknologi informasi dalam pembelajaran. Pengembangan pembelajaran dengan menggabungkan teknologi informasi memberikan andil yang sangat penting terhadap level praktik pedagogis terhadap peserta didik (Brun \& Hinostroza, 2014).

Memasuki abad dimana teknologi sangat memiliki peran yang sangat penting dalam kehidupan sehari-hari seorang guru sebaiknya mempunyai keterampilan dalam penguasaan teknologi yang baik. Perkembangan teknologi dan informasi yang amat begitu cepat pada era saat ini menjadikan dan membuat tantangan bagi dunia pendidikan untuk menemukan serta mengembangkan suatu metode, alat maupun metode yang meningkatkan daya guna dan hasil bagi kegiatan belajar mengajar. Kehadiran teknologi memegang dampak yang penting bagi lembaga pendidikan maupun sekolah karena serupa suatu instrumen dan sarana yang menuntut guru dan peserta didik untuk menggunakan teknologi dalam mencari, mengelola dan menilai suatu informasi untuk memecahkan masalah (Srisawasdi, 2012). Oleh karena itu, kompetensi guru untuk mengkombinasikan teknologi pada pelaksanaan belajar mengajar sangat diperlukan di era revolusi industri saat ini. Diperlukan sebuah pendekatan maupun metode yang menetapkan bahwa mengajar merupakan hubungan antar pengetahuan yang guru telah pahami dan dengan cara apa mereka mengimplementasikan pengetahuan guru yang telah dipahami dalam proses pembelajaran di dalam kelas. Tidak ada satu langkah yang terbaik untuk mengkombinasikan teknologi ke dalam program pembelajaran. Sebagai alternatif, sebagai usaha menggabungkan harus secara inovatif dirancang dan dikembangkan untuk disiplin ilmu atau topik khusus dalam konteks kelas khusus (Koehler \& Mishra, 2009).

Berdasarkan ide yang diusulkan oleh Shulman terkait Pedagogical Content Knowledge, Mishra \& Koehler (2006) sudah 
menyisipkan kompetensi teknologi pada Pedagogical Content Knowledge, dengan sebutan TPACK (technological, pedagogical, and content knowledge). TPACK merupakan suatu bingkai kerja yang menguji menguasai keterkaitan antara pengetahuan terkait ilmu mendidik (pedagogical knowledge), disiplin ilmu atau isi pembelajaran (content knowledge), dan pemanfaatan teknologi dalam pembelajaran (technological knowledge). Pada bingkai kerja TPACK, pemahaman, pengetahuan dan keterampilan guru dalam mengkombinasikan teknologi pada proses pembelajaran menjadikan kegiatan belajar mengajar menjadi menyenangkan, efektif serta tepat guna. Hal ini juga dapat diterapkan pada pembelajaran di jurusan teknika kapal penangkap ikan agar pembelajaran dapat mengintegrasikan teknologi dalam pembelajaran seperti penggunaan media media digital, simulator kapal, augmented reality, virtual reality, kelas daring dan lain sebagainya. Kemampuan untuk terus belajar dan mencari tahu tentang teknologi terbaru yang dapat digunakan dalam pembelajaran sangat penting mengingat teknologi terus berkembang sangat pesat.

Misalnya, perkembangan software dalam pembelajaran mulai dari powerpoint, kinemaster, canva hingga saat ini muncul teknologi Augmented Reality. Softwaresoftware tersebut dapat digunakan untuk proses pembelajaran (Sintawati \& Indriani, 2019). Kombinasi teknologi dirasa seperti elemen dan bagian pembelajaran dan tergolong dalam Pedagogical Content Knowledge (Oyanagi \& Satake, 2016).

Pengkombinasian teknologi dalam kegiatan belajar mengajar termasuk dalam pembelajaran di SMK jurusan teknika kapal penangkap ikan merupakan hal yang sangat perlu diimplementasikan oleh guru SMK produktif teknika kapal penangkap ikan. Proses pembelajaran di mata pelajaran produktif teknika kapal penangkap ikan tidak hanya belajar dengan teori dan menghafal pengetahuan melainkan harus melakukan praktik kerja langsung, mengalami, melakukan-

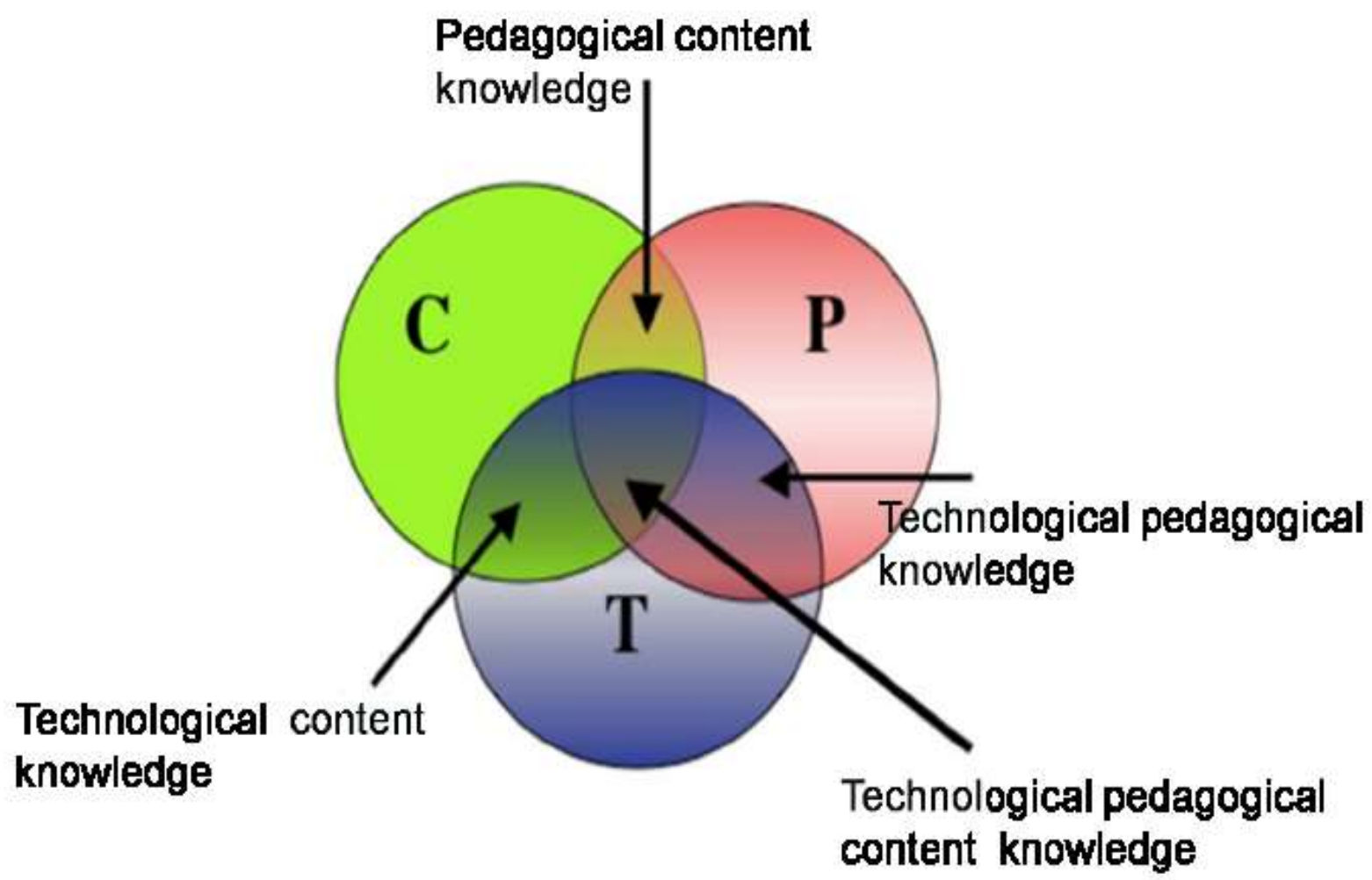

Gambar 1. Kerangka Kerja TPACK 
sesuatu dan menyelesaikan kerumitan dengan semua elemen yang terkait dengannya. Banyak materi pembelajaran di SMK jurusan teknika kapal penangkap ikan yang sulit diserap oleh peserta didik, apalagi materi yang bersifat abstrak seperti sistem kerja mesin kapal, sehingga peran ilustrasi dibutuhkan untuk mempermudah peserta didik dalam mengenal dan menyerap informasi dan isi materi pembelajaran. (Gilbert, 2005) dan Ainsworth (2008) mengungkapkan bahwa representasi merupakan suatu alat yang penting dalam mengkomunikasikan konsep yang bersifat abstrak dan kompleks. Penggunaan representasi visual tidak lepas dari pemanfaatan teknologi informasi salah satunya penggunaan augmented reality. Oleh karena itu pengintegrasian teknologi informasi dalam proses pembelajaran dipandang perlu diimplementasikan oleh guru untuk mengakomodasi peserta didik dalam menyerap dan mempelajari informasi penting dan isi dalam materi pembelajaran. Kemampuan guru dalam pengintegrasian teknologi yang tepat contohnya augmented reality dengan materi pembelajaran saat mengajarkan pelajaran teknika kapal ikan dengan materi mesin kapal sangat penting untuk dikuasai oleh guru dalam artian guru tersebut harus memiliki kemampuan TPACK. Disaat guru mampu menerapkan kemampuan TPACK dalam merencanakan dan mengimplementasikan TPACK dalam pembelajaran, diharapkan dapat mengefisiensikan dan mengefektifkan pembelajaran. Pola peningkatan keterampilan technological, pedagogical, and content knowledge adalah sebuah ide dan pandangan yang sangat diperlukan untuk mengembangkan dan meningkatkan mutu pembelajaran sesuai dengan perkembangan zaman yang berlangsung (Hidayati et al., 2019). Sebagai langkah awal dalam penelitian ini akan dilakukan analisa dan pengamatan terhadap kemampuan TPACK guru SMK teknika kapal penangkap ikan.

\section{METODE}

Penelitian ini merupakan upaya untuk mencari dan menganalisis serta membuktikan sesuatu. Studi ini memakai metode pendekatan deskriptif dengan teknik kuantitatif. Studi deskriptif ini adalah studi yang benar-benar paling efektif menggambarkan apa yang terkandung atau terjadi dalam adegan, disiplin, atau area tertentu. Pendekatan kuantitatif digunakan untuk memperoleh hasil berupa angka angka melalui skor jawaban dan penggunaan penilaian baik deduktif dalam peningkatan dan pemeriksaan prinsipnya sebagaimana digunakan dalam ilmu-ilmu aktual dan ilmu humaniora yang memiliki pemikiran tentang semua kejadian sebagai tujuan beberapa hal. Studi kuantitatif banyak yang diharuskan untuk menerapkan angka, mulai dari pengumpulan fakta, interpretasi fakta, dan interpretasi pada hasil. Sedangkan pada pelaksanaan pengambilan data menggunakan metode survey terhadap 12 guru dari total 20 guru pada 8 SMK Teknika Kapal Penangkap Ikan yang tergabung di Musyawarah Guru Mata Pelajaran (MGMP) Teknika Kapal Penangkap Ikan Provinsi Jawa Timur yang diambil sampel secara acak sebanyak 12 orang guru atau sebanyak $60 \%$ dari total guru SMK Teknika Kapal Penangkap Ikan. Studi ini menggunakan alat penelitian berupa angket tertutup. Adapun yang menjadi objek dalam riset ini adalah kompetensi TPACK guru SMK Teknika Kapal Penangkap Ikan Provinsi Jawa Timur. Tahapan penelitian awal adalah tahapan melaksanakan persiapan penelitian.

Tabel 1 Kategori Interpretasi

\begin{tabular}{ll}
\hline \multicolumn{1}{c}{ Interval } & Kategori \\
\hline$M+1,5 S D<X$ & Sangat Baik \\
$M+0,5 S D<X<M+1,5 S D$ & Baik \\
$M-0,5 S D<X<M+1,5 S D$ & Cukup \\
$M-0,5 S D<X<M-1,5 S D$ & Kurang Baik \\
$X<M-1,5 S D$ & Tidak Baik \\
\hline \multicolumn{2}{c}{ (Diadaptasi dari Azwar (2007) }
\end{tabular}


Dalam tahap ini perlu mengumpulkan studi literatur, melakukan pemilihan dan penentuan lokasi penelitian, serta sampel penelitian. Pada tahapan pelaksanaan penelitian akan menghasilkan data data berupa data angket dan hasil wawancara. Tahapan selanjutnya dilakukan analisa dan pengolahan data yang didapatkan serta dilanjutkan dengan pembahasan dan penarikan kesimpulan untuk penyempurnaan penyusunan laporan penelitian. Untuk mengambil keputusan interpretasi data dengan menggunakan skor total sebagai acuannya. Rumus pengkategoriannya adalah sebagaimana tersaji pada tabel 1.

Dalam penelitian ini, digunakan beberapa indikator TPACK melingkupi Pedagogical Knowledge (PK), Technological knowledge (TK), Content Knowledge (CK), Technological Content Knowledge (TCK), Pedagogical Content Knowledge (PCK), Technological Content Knowledge (TPK), Technological, Pedagogical and Content Knowledge (TPACK). Dengan menggunakan alat ukur angket TPACK. Data-data pada setiap indikator tersebut dianalisis untuk mencari data dan dipilah sesuai dengan bagian bagian bingkai kerja TPACK sehingga dapat ditemukan bagian bagian yang dikategorikan dan dikelompokkan ke dalam tabel kategori interpretasi.

\section{HASIL}

Hasil analisis terhadap informasi yang terkumpul pada kuesioner TPACK guru SMK jurusan Teknika Kapal Penangkap Ikan rekapitulasinya disajikan pada Tabel 2. Tabel 2 menunjukkan bahwa rata-rata kemampuan TPACK guru SMK Teknika Kapal Penangkap Ikan berada di dalam kelompok baik, dengan data teratas terdapat pada bagian Content Knowledge atau pengetahuan isi materi. Hal ini dapat dipahami karena 10 dari 12 responden guru SMK Teknika Kapal Penangkap Ikan -
Tabel 2 Rekapitulasi setiap bagian TPACK

\begin{tabular}{|c|c|c|}
\hline Bagian TPACK & $M$ & Kriteria \\
\hline Content Knowledge (CK) & 3.44 & $\begin{array}{l}\text { Sangat } \\
\text { Baik }\end{array}$ \\
\hline $\begin{array}{l}\text { Technological Knowledge } \\
\text { (TK) }\end{array}$ & 2.68 & Cukup \\
\hline Pedagogical Knowledge (PK) & 3.17 & Baik \\
\hline $\begin{array}{l}\text { Technological Content } \\
\text { Knowledge (TCK) }\end{array}$ & 2.87 & Baik \\
\hline $\begin{array}{l}\text { Pedagogical Content } \\
\text { Knowledge (PCK) }\end{array}$ & 3.36 & Baik \\
\hline $\begin{array}{l}\text { Technological } \\
\text { Pedagogical }\end{array}$ & 2.64 & Cukup \\
\hline $\begin{array}{l}\text { Knowledge (TPK) } \\
\text { Technological }\end{array}$ & & \\
\hline $\begin{array}{l}\text { Pedagogical Content } \\
\text { Knowledge (TPCK) }\end{array}$ & 2.85 & Baik \\
\hline Rata-rata & 3.00 & Baik \\
\hline
\end{tabular}

yang memiliki latar belakang ilmu murni (non kependidikan) yang berasal dari Sekolah Tinggi Perikanan.

Dengan demikian pengetahuan para guru SMK tersebut terhadap isi materi pelajaran sangat tinggi. Data pada tabel 2 juga menunjukkan 2 bagian yang rata-ratanya berada dalam kategori cukup yaitu Technological Knowledge (TK) dan Technological Pedagogical Knowledge (TPK). Hal ini dapat dimaknai bahwa guru SMK Teknika Kapal Penangkap Ikan tidak belajar banyak terkait integrasi teknologi dalam pembelajaran di dunia perkuliahan. Setiap hasil analisis bagian TPACK dijabarkan sebagai berikut.

Technological Knowledge

Technological knowledge bertumpu kepada keterampilan dan pengetahuan terkait berbagai teknologi dari low-technology hingga teknologi digital yang dapat diimplementasikan dalam kurikulum dan pembelajaran serta mengacu pada keterampilan dalam menggunakannya (De Rossi \& Trevisan, 2018). Hasil penjabaran data terhadap angket keterampilan teknologi dapat dilihat dari data tabel 3. Tabel 3 menunjukkan bahwa analisis deskriptif variabel Technological Knowledge memiliki skor rata-rata sebesar 2.68. 
Tabel 3 Analisis Deskripsi Variabel TK

\begin{tabular}{lc}
\hline \multicolumn{2}{c}{ Technological Knowledge } \\
\hline Rata-rata & 2.68 \\
Standard Error & 0.06 \\
Median & 2.68 \\
Modus & 2.93 \\
Standar Deviasi & 0.22 \\
Sample Variance & 0.05 \\
Kurtosis & -1.38 \\
Skewness & -0.05 \\
Rentang & 0.60 \\
Minimum & 2.30 \\
Maksimum & 3.00 \\
Sum & 32.21 \\
Kalkulasi & 12.00 \\
\hline Sumber: Data Diolah
\end{tabular}

Sumber: Data Diolah Menggunakan Microsoft Excel, 2020

Berdasarkan interpretasi informasi data yang telah direpresentasikan pada tabel 3 menunjukkan bahwa kemampuan technological knowledge atau pengetahuan teknologi pada guru SMK Teknika Kapal Penangkap Ikan berada dalam kategori cukup. Hal ini menandakan bahwa beberapa guru SMK teknika kapal penangkap ikan belum semuanya dapat mengolah dan memperoleh pengetahuan teknologi informasi dan mengikuti perkembangan teknologi. Data dari hasil wawancara dengan Bapak Omo Taryomo, S.St.Pi bahwa para guru SMK Teknika kapal penangkap ikan baru dapat memanfaatkan teknologi video pembelajaran dalam menyampaikan materi seperti mesin mesin kapal penangkap ikan.

Content Knowledge (CK)

Pengetahuan terkait disiplin ilmu isi materi pembelajaran atau Content Knowledge berpatokan pada pemahaman terkait isi materi pelajaran yang harus dimiliki dan dikuasai saat mengajar (Spector et al., 2014), dalam konteks penelitian ini adalah materi di jurusan teknika kapal penangkap ikan salah satunya adalah materi mesin.
Tabel 4 Analisis Deskripsi Variabel CK

\begin{tabular}{ll}
\hline \multicolumn{2}{c}{ Content Knowledge } \\
\hline Rata-rata & 3.44 \\
Standard Error & 0.06 \\
Median & 3.42 \\
Modus & 3.33 \\
Standar Deviasi & 0.21 \\
Sample Variance & 0.04 \\
Kurtosis & 0.13 \\
Skewness & -0.50 \\
Rentang & 0.75 \\
Minimum & 3.00 \\
Maksimum & 3.75 \\
Sum & 41.25 \\
Kalkulasi & 12.00 \\
\hline
\end{tabular}

Sumber: Data Diolah Menggunakan Microsoft Excel, 2020

Data informasi yang termuat dalam tabel 4 menunjukkan bagian pengetahuan disiplin ilmu atau content knowledge guru SMK jurusan Teknika Kapal Penangkap Ikan menunjukkan pada kelompok sangat baik dengan rata-rata nilai 3.44. Apabila seorang guru saat ini tidak memiliki keahlian yang benar terkait dengan materi mengenal sehingga seseorang dapat diajari itu dapat menyebabkan kesalahpahaman dalam menampilkan informasi (Koehler \& Mishra, 2009).

\section{Pedagogical Knowledge}

Pengetahuan cara mengajar atau Pedagogical Knowledge mengacu kepada pemahaman terkait karakteristik peserta didik, strategi pembelajaran, evaluasi pembelajaran, serta perencanaan pembelajaran. Hasil penjabaran pengumpulan data angket pada bagian ilmu mengajar atau Pedagogical Knowledge dijabarkan pada tabel 5.

Dari hasil pengolahan data untuk analisis deskripsi variabel Pedagogical Knowledge guru jurusan teknika kapal penangkap ikan memiliki nilai rata-rata dengan nilai 3.17 dengan menunjukkan pada kelompok baik. 
Tabel 5 Analisis Deskripsi Variabel PK

\begin{tabular}{lc}
\hline \multicolumn{2}{c}{ Pedagogical Knowledge } \\
\hline Rata-rata & 3.17 \\
Standard Error & 0.08 \\
Median & 3.05 \\
Modus & 3.50 \\
Standar Deviasi & 5.48 \\
Sample Variance & 0.08 \\
Kurtosis & -1.48 \\
Skewness & 0.63 \\
Rentang & 0.75 \\
Minimum & 2.85 \\
Maksimum & 3.60 \\
Sum & 38.00 \\
Kalkulasi & 12.00 \\
\hline
\end{tabular}

Sumber: Data Diolah Menggunakan Microsoft Excel, 2020

Hal ini berarti bahwa guru SMK teknika kapal ikan dapat mengetahui dan mampu mengimplementasikan prinsip, konseptual maupun prosedural ilmu pedagogi yang terdiri dari perencanaan, pelaksanaan dan penilaian pembelajaran.

Hasil tersebut didukung oleh fakta bahwa selama menjadi guru, guru harus mengikuti Pelatihan Profesi Guru (PPG) dalam meningkatkan pengetahuan pedagogi mereka. Informasi pedagogis adalah pemahaman yang sangat kritis dan perlu dikuasai oleh guru. Seperti yang dikatakan dalam UU tentang guru dan dosen No. 14 tahun 2005 bahwa salah satu talenta yang harus dimiliki dengan bantuan guru dan dosen adalah keterampilan pedagogis.

Technological Content Knowledge

Kompetensi dan pemahaman terkait interaksi timbal balik antara disiplin ilmu atau isi mata pelajaran dengan teknologi atau dikenal dengan istilah Technological Content Knowledge (TCK) (Spector et al., 2014). Hasil penjabaran data terhadap angket interaksi disiplin ilmu dan teknologi atau Technological Content Knowledge diinterpretasikan pada tabel 6.
Tabel 6 Analisis Deskripsi Variabel TCK

Technological Content Knowledge

\begin{tabular}{ll}
\hline Rata-rata & 2.85 \\
Standard Error & 0.06 \\
Median & 2.90 \\
Modus & 3.00 \\
Standar Deviasi & 0.21 \\
Sample Variance & 0.05 \\
Kurtosis & 0.90 \\
Skewness & -0.80 \\
Rentang & 0.80 \\
Minimum & 2.40 \\
Maksimum & 3.20 \\
Sum & 34.40 \\
Kalkulasi & 12.00
\end{tabular}

Sumber: Data Diolah Menggunakan Microsoft Excel, 2020

Dari hasil pengolahan data untuk analisis deskripsi variabel Technological Content Knowledge guru jurusan teknika kapal penangkap ikan memiliki nilai rata-rata sebesar 2.85 dengan kelompok baik. Hal ini dapat diartikan bahwa guru SMK teknika kapal penangkap ikan telah memahami dan mengimplementasikan teknologi dalam penyampaian informasi dan konten dalam pembelajaran dengan baik. TCK adalah pengetahuan bagaimana teknologi mampu berpengaruh dan dapat diimplementasikan dalam penggalian ilmu dan materi terbaru.

Pedagogical Content Knowledge

Pemahaman terkait interaksi dengan cara apa subjek atau kesulitan tertentu dalam sebuah ruang lingkup ilmu dapat dipresentasikan, dikelola dan diatur dengan keragaman bakat minat serta keunikan peserta didik dan dilaksanakan dalam kegiatan belajar mengajar atau dikenal dengan istilah Pedagogical Content Knowledge (PCK) (Shulman, 1987). Hasil penjabaran data terhadap angket bagaimana mengajarkan isi materi atau Pedagogical Content Knowledge diinterpretasikan pada tabel 7. Dari hasil pengolahan data untuk analisis deskripsi variabel Pedagogical Content Knowledge guru jurusan teknika kapal penangkap ikan memiliki rata- rata skor sebanyak 3.36 dengan kategori kelompok baik. 
Tabel 7 Analisis Deskripsi Variabel PCK

\begin{tabular}{lc}
\hline \multicolumn{1}{c}{ Pedagogical Content Knowledge } \\
\hline Rata-rata & 3.36 \\
Standard Error & 0.07 \\
Median & 3.31 \\
Modus & 3.63 \\
Standar Deviasi & 0.23 \\
Sample Variance & 0.05 \\
Kurtosis & -1.54 \\
Skewness & -0.07 \\
Rentang & 0.63 \\
Minimum & 3.00 \\
Maksimum & 3.63 \\
Sum & 40.38 \\
Kalkulasi & 12.00 \\
\hline
\end{tabular}

Sumber: Data Diolah Menggunakan Microsoft Excel, 2020

Hal ini dapat diartikan guru SMK teknika kapal penangkap ikan telah mampu mengintegrasikan pengetahuan pedagogi dengan konten materi yang akan diajarkan menggunakan pendekatan maupun strategi model pembelajaran.

Technological Pedagogical Knowledge

Pengetahuan terkait dengan cara apa beragam teknologi bisa dimanfaatkan dalam kegiatan mengajar, dan mengetahui bahwa cara guru dalam mengajar dapat diubah menggunakan teknologi atau dikenal dengan Technological Pedagogical Knowledge (PCK). Hasil penjabaran data terhadap angket bagaimana mengkombinasikan dan memanfaatkan teknologi dalam kegiatan mengajar atau Technological Pedagogical Knowledge diinterpretasikan pada tabel 8.Dari hasil pengolahan data untuk analisis deskripsi variabel Technological Pedagogical Knowledge guru jurusan teknika kapal penangkap ikan memiliki nilai rata-rata sebanyak 2.64 dengan kategori kelompok cukup. Hal ini dimungkinkan karena terbatasnya sarana teknologi di sekolah, sehingga penggunaan teknologi menjadi terbatas dalam mengajar.
Tabel 8 Analisis Deskripsi Variabel TPK

\begin{tabular}{lc}
\hline Technological Pedagogical Knowledge \\
\hline Rata-rata & 2.64 \\
Standard Error & 0.04 \\
Median & 2.70 \\
Modus & 2.70 \\
Standar Deviasi & 0.14 \\
Sample Variance & 0.02 \\
Kurtosis & 2.66 \\
Skewness & -1.42 \\
Rentang & 0.50 \\
Minimum & 2.30 \\
Maksimum & 2.80 \\
Sum & 31.70 \\
Kalkulasi & 12.00 \\
\hline
\end{tabular}

Sumber: Data Diolah Menggunakan Microsoft Excel, 2020

Technological Pedagogical and Content Knowledge

Pemahaman terkait pengintegrasian teknologi ke dalam proses belajar mengajar pada disiplin ilmu pembelajaran tertentu disebut dengan istilah Technological Pedagogical and Content Knowledge (TPCK). Hasil analisis data angket pada bagian Technological Pedagogical and Content Knowledge diinterpretasikan pada tabel 9.

Tabel 9 Analisis Deskripsi Variabel TPCK

Technological Pedagogical and Content Knowledge

\begin{tabular}{ll}
\hline Rata-rata & 2.85 \\
Standard Error & 0.06 \\
Median & 3.00 \\
Modus & 3.00 \\
Standar Deviasi & 0.20 \\
Sample Variance & 0.04 \\
Kurtosis & -0.46 \\
Skewness & -0.99 \\
Rentang & 0.50 \\
Minimum & 2.50 \\
Maksimum & 3.00 \\
Sum & 34.25 \\
Kalkulasi & 12.00 \\
\hline
\end{tabular}

Sumber: Data Diolah Menggunakan Microsoft Excel, 2020 
Hasil penjabaran data terhadap angket bagaimana mengintegrasikan teknologi ke dalam proses belajar mengajar pada disiplin ilmu pembelajaran tertentu diinterpretasikan pada tabel 9 . Dari hasil pengolahan data untuk analisis deskripsi variabel Technological Pedagogical and Content Knowledge guru jurusan teknika kapal penangkap ikan memiliki nilai rata-rata dengan nilai 2.85 dengan kategori kelompok baik. Dari hasil analisis tersebut, dapat dimaknai bahwa guru teknika kapal penangkap ikan telah memahami pengintegrasian teknologi, pedagogi, dan materi pembelajaran.

\section{PEMBAHASAN}

Hasil analisis data angket keseluruhan bagian TPACK terhadap guru SMK Jurusan Teknika Kapal Penangkap Ikan yang terdapat pada tabel 2 menunjukkan bahwa responden memiliki pengetahuan yang rendah di bagian Technological Knowledge (TK) dengan skor 2,68, bagian Technological Content Knowledge dengan skor 2.87 dan Technological Pedagogical Knowledge (TPK) dengan skor 2,64. Hal ini dapat dilihat bahwa guru belum mempunyai pengetahuan dan keterampilan memanfaatkan teknologi dalam pembelajaran. Hasil wawancara juga menunjukkan bahwa guru hanya sedikit melibatkan peserta didik dalam pemanfaatan teknologi klasik misalkan, pemanfaatan aplikasi pengolah kata, pengolah angka, aplikasi pengolah gambar sederhana (Microsoft Paint) dan penayangan video pembelajaran.

Penggunaan video pembelajaran sebagai media untuk memvisualisasikan materi merupakan pilihan yang tepat karena dapat meningkatkan konsep dan pemahaman peserta didik daripada hanya menggu-nakan bahan ajar teks (Stelzer et al., 2009). Namun untuk pemanfaatan teknologi yang lebih kompleks para guru masih belum memahami lebih dalam. Para guru telah sadar belum cukup menguasai pemahaman dan keterampilan yang cukup dalam memanfaatkan teknologi yang beragam dan terkini dalam sebuah kegiatan pembelajaran (Sholihah \& Kristanto, 2015).

Perubahan spektrum kurikulum pada SMK jurusan Teknika Kapal Penangkap Ikan yang memuat mata pelajaran simulasi komunikasi digital memiliki misi untuk mentransfer pemahaman dan keterampilan teknologi serta dunia digital kepada peserta didik SMK jurusan Teknika Kapal penangkap Ikan. Pengetahuan dan keterampilan teknologi dan dunia digital seharusnya juga dimiliki oleh guru SMK jurusan teknika kapal penangkap ikan mengingat mata pelajaran simulasi komunikasi digital masuk ke dalam kelompok $\mathrm{C}$ (kelompok mata pelajaran produktif/ kejuruan).

Perkembangan pesat pada perangkat mobile dan kehadiran internet tidak secara otomatis membuat para guru dapat memahami pengintegrasian TPACK dalam kegiatan belajar mengajar. Hal ini dapat disebabkan karena pemanfaatan teknologi yang digunakan hanya sekedar melihat video, mengetik dan mengolah gambar sederhana. Hal ini didukung oleh penelitian lain bahwa guru atau pembelajar di era digital menggunakan teknologi di kehidupan seharihari namun belum terbiasa dalam penggunaan teknologi dalam pembelajaran (Waycott et al., 2010). Tingginya pemanfaatan teknologi bagi guru belum tentu berbanding lurus dengan penggunaan teknologi dalam kegiatan belajar mengajar guru di dalam kelas (Koh et al., 2014).

Perlunya kolaborasi antara guru dan kebijakan dari kepala sekolah dalam memaksimalkan pemanfaatan teknologi dalam pembelajaran di era digital karena pembelajar digital membutuhkan bantuan tentang cara memanfaatkan teknologi secara efektif untuk belajar (Gurung \& Rutledge, 2014). Seorang guru harus dapat memanfaatkan teknologi secara efektif dan mengintegrasikan dalam pembelajaran. Hal dasar yang perlu dipahami oleh guru adalah literasi digital. Literasi digital tidak hanya sekedar mengetahui cara 
mengoperasikan teknologi, melainkan memiliki keteram-pilan berpikir kritis dan manajemen informasi yang tepat (Tang \& Chaw, 2015). Literasi digital atau literasi teknologi adalah kemampuan dalam memanfaatkan teknologi, menyelesaikan masalah secara kolaboratif serta mampu mengidentifikasi dan mengevaluasi informasi dengan cara yang benar dari berbagai sumber (Hoffmann, 2014).

Di era revolusi industri sangat diperlukan kemampuan seorang guru yang mengikuti perkembangan jaman. Seorang guru profesional pada abad 21 adalah figur yang dapat memerankan diri sebagai pembelajar sepanjang masa dan sepanjang karir. Hal itu bertujuan meningkatkan daya guna dan efisiensi kegiatan belajar mengajar peserta didik. Upaya tersebut dapat dilakukan dalam bentuk pegembangan diri yang mendukung keahliannya (Surahman et al., 2020). Pendidik diharapkan dapat belajar dan berkolaborasi sebagai usaha menghadapi dorongan visi misi sekolah dan kegiatan mengajar, mampu membimbing dan berkomunikasi secara cakap serta mampu menggunakan teknologi secara efektif dalam pembelajaran. Untuk dapat aktif sebagai guru di era pembelajaran yang dikombinasikan dengan teknologi sosok guru harus mampu mengoperasikan teknologi dengan baik.

Upaya meningkatkan penggunaan teknologi dimanapun, perlu disertai dengan mendorong guru untuk berpartisipasi dalam kegiatan pengembangan professional, teknologi, pedagogi dan konten pembelajaran perlu menjadi patokan dalam peningkatan dan pengembangan guru profesional (Praherdhiono et al., 2019). Berbagai kajian penelitian menunjukkan bahwa pembelajaran yang meliputi masukan, pemrosesan dan capaian pendidikan dapat ditingkatkan melalui pemanfaatan teknologi (Davies \& West, 2014). Berbagai penelitian juga menyebutkan bahwa integrasi teknologi, pedagogi, dan konten pembelajaran telah mempengaruhi beberapa penelitian, teori maupun praktik dalam pendidikan guru dan pengebangan keprofesian guru (Ifinedo et al., 2020; Praherdhiono et al., 2020). Figur guru dapat disebut sebagai guru yang cakap jika berpijak dan mengacu dalam penguasaan secara teoritis maupun praktis untuk mengintegrasikan teknologi, kemampuan pedagogi dan bagaimana menyusun dan mengajarkan konten pembelajaran secara efektif (Castéra et al., 2020).

Walaupun perkembangan zaman saat ini telah didominasi oleh pemanfaatan teknologi, peran seorang guru masih sangat dibutuhkan dalam pembelajaran dikarenakan sebagai otak dan penggerak dalam mengintegrasikan teknologi tersebut. Peran ini yang harus dikembangkan dan ditingkatkan melalui pelatihan ataupun sebagainya.

\section{SIMPULAN}

Di era perkembangan teknologi saat ini, seorang guru teknika kapal penangkap ikan harus dapat mengintegrasikan pengetahuan terkait teknologi, pedagogi dan materi teknika kapal penangkap ikan. Hasil penelitian analisis ini menunjukkan bahwa kemampuan dari bagian-bagian TPACK guru teknika kapal penangkap ikan berada dalam kategori baik. Namun, perlu menjadi kajian dan penelitian untuk selanjutnya terkait hasil analisis kemampuan guru teknika kapal penangkap ikan pada bagian yang memiliki rata-rata dengan kategori cukup pada bagian Technological Knowledge dan Technological Pedagogical Knowledge.

\section{REFERENSI}

Ainsworth, S. (2008). The educational value of multiple-representations when learning complex scientific concepts. In Visualization: Theory and practice in science education (pp. 191-208). Springer.

Arbianto, U. F., Widiyanti, W., \& Nurhadi, D. (2019). Kesiapan Technological, Pedagogical And Content Knowledge (Tpack) Calon Guru Bidang Teknik di Universitas Negeri Malang. 
Jurnal Teknik Mesin Dan Pembelajaran, 1(2), 1-9.

Azwar, S. (2007). Sikap manusia: Teori dan pengukurannya.

Ball, D. L., Thames, M. H., \& Phelps, G. (2008). Content knowledge for teaching: What makes it special. Journal of Teacher Education, 59(5), 389-407.

Brun, M., \& Hinostroza, J. E. (2014). Learning to become a teacher in the 21st century: ICT integration in Initial Teacher Education in Chile. Journal of Educational Technology \& Society, 17(3), 222-238. https://www.jstor.org/stable/jeductech soci.17.3.222

Castéra, J., Marre, C. C., Yok, M. C. K., Sherab, K., Impedovo, M. A., Sarapuu, T., Pedregosa, A. D., Malik, S. K., \& Armand, H. (2020). Self-reported TPACK of teacher educators across six countries in Asia and Europe. Education and Information Technologies, 25(1), 30033019.

https://doi.org/https://doi.org/10.1007 /s10639-020-10106-6

Davies, R. S., \& West, R. E. (2014). Technology integration in schools. In Handbook of research on educational communications and technology (pp. 841-853). Springer, New York, NY. https://doi.org/https://doi.org/10.1007 /978-1-4614-3185-5_68

De Rossi, M., \& Trevisan, O. (2018). Technological Pedagogical Content Knowledge in the literature: how TPCK is defined and implemented in initial teacher education. Italian Journal of Educational Technology, 26(1), 7-23.

Gilbert, J. K. (2005). Visualization: A metacognitive skill in science and science education. In Visualization in science education (pp. 9-27). Springer. https://doi.org/https://doi.org/10.1007 /1-4020-3613-2_2

Gurung, B., \& Rutledge, D. (2014). Digital learners and the overlapping of their personal and educational digital engagement. Computers \& Education, 77, 91-100. https://doi.org/https://doi.org/10.1016 /j.compedu.2014.04.012https://doi.org/ 10.1016/j.compedu.2014.04.012
Hidayati, N., Setyosari, P., \& Soepriyanto, Y. (2019). Kompetensi Technological Pedagogical Content Knowledge (TPACK) Guru SOSHUM Setingkat SMA. Jurnal Kajian Teknologi Pendidikan, 1(4), 291-298.

Hoffmann, B. (2014). Computer as a Threat or an Opportunity for Development of Children. Procedia-Social and Behavioral Sciences, 146, 15-21.

https://doi.org/https://doi.org/10.1016/j.sbs pro.2014.08.080

Ifinedo, E., Rikala, J., \& Hämäläinen, T. (2020). Factors affecting Nigerian teacher educators' technology integration: Considering characteristics, knowledge constructs, ICT practices and beliefs. Computers \& Education, 146, 103760. https://doi.org/https://doi.org/10.1016/j.co mpedu.2019.103760

Indonesia, U.-U. R. (2005). Undang-undang RI No. 14 tahun 2005 tentang Guru dan Dosen. https://jdih.kemenkeu.go.id/fulltext/2005/14 tahun2005uu.htm

Kaufman, D. M. (2003). Applying educational theory in practice. $A B C$ of Learning and Teaching in Medicine, 326(7382), 213-216. https://doi.org/https://doi.org/10.1136/bmj. 326.7382.213

Koehler, M., \& Mishra, P. (2009). What is technological pedagogical content knowledge (TPACK)? Contemporary Issues in Technology and Teacher Education, 9(1), 60-70.

Koh, J. H. L., Chai, C. S., \& Tay, L. Y. (2014). TPACKin-Action: Unpacking the contextual influences of teachers' construction of technological pedagogical content knowledge (TPACK). Computers \& Education, 78, 20-29. https://doi.org/https://doi.org/10.1016/j.co mpedu.2014.04.022

Loughran, J., Berry, A., \& Mulhall, P. (2012). Understanding and developing scienceteachers' pedagogical content knowledge (Vol. 12). Springer Science \& Business Media.

Mishra, P., \& Koehler, M. J. (2006). Technological pedagogical content knowledge: A framework for teacher knowledge. Teachers College Record, 108(6), 1017-1054.

Oyanagi, W., \& Satake, Y. (2016). Capacity building in technological pedagogical content knowledge for preservice teacher. International Journal for Educational Media 
and Technology, 10(1), 33-44.

Praherdhiono, H., Adi, E. P., Prihatmoko, Y., Nindigraha, N., Soepriyanto, Y., Indreswari, H., \& Oktaviani, H. I. (2020). Implementasi Pembelajaran Di Era Dan Pasca Pandemi Covid-19. Seribu Bintang. Praherdhiono, H., Setyosari, P., Degeng, I. N. S., Slamet, T. I., Surahman, E., Adi, E. P., Degeng, M. D. K., \& Abidin, Z. (2019). Teori dan Implementasi Teknologi Pendidikan: Era Belajar Abad 21 dan Revolusi Industri 4.0. Seribu Bintang.

Ruhrig, J., \& Höttecke, D. (2015). Components of science teachers' professional competence and their orientational frameworks when dealing with uncertain evidence in science teaching. International Journal of Science and Mathematics Education, 13(2), 447-465. https://doi.org/https://doi.org/10.1007 /s10763-015-9628-3

Sagala, S. (2009). Kemampuan Profesional Guru dan Tenaga Kependidikan: Pemberdayaan guru, tenaga kependidikan, dan masyarakat dalam manajemen sekolah. CV. Alfabeta.

Sholihah, H., \& Kristanto, A. (2015). Pengembangan Multimedia Modul Interaktif Berbasis Android Materi Editing Audio pada Mata Kuliah Pengembangan Media Audio di Program Studi Teknologi Pendidikan Universitas Negeri Surabaya. Jurnal Mahasiswa Teknologi Pendidikan, 6(2).

Shulman, L. (1987). Knowledge and teaching: Foundations of the new reform. Harvard Educational Review, 57(1), 1-23. https://doi.org/https://doi.org/10.1776 3/haer.57.1.j463w79r56455411

Sintawati, M., \& Indriani, F. (2019). Pentingnya Technological Pedagogical Content Knowledge (TPACK) Guru di Era Revolusi
Industri 4.0. Prosiding Seminar Nasional Pagelaran Pendidikan Dasar Nasional (PPDN) 2019, 1(1), 417-422. http://seminar.uad.ac.id/index.php/ppdn/art icle/view/1355

Spector, J. M., Merrill, M. D., Elen, J., \& Bishop, M. J. (2014). Handbook of research on educational communications and technology. Springer.

Srisawasdi, N. (2012). The role of TPACK in physics classroom: case studies of preservice physics teachers. Procedia-Social and Behavioral Sciences, 46, 3235-3243. https://doi.org/https://doi.org/10.1016/j.sbs pro.2012.06.043

Stelzer, T., Gladding, G., Mestre, J. P., \& Brookes, D. T. (2009). Comparing the efficacy of multimedia modules with traditional textbooks for learning introductory physics content. American Journal of Physics, 77(2), 184-190.

https://doi.org/https://doi.org/10.1119/1.30 28204

Surahman, E., Sulthoni, S., Ulfa, S., Husna, A., Ramdiana, H., Thaariq, Z. Z. A., Setiawan, A. B., \& Qolbi, M. S. (2020). Pelatihan Micro Learning Object Berbasis TPACK bagi GuruGuru SMA di Garut. Abdimas Pedagogi: Jurnal Ilmiah Pengabdian Kepada Masyarakat, 3(1), 1-14.

Tang, C. M., \& Chaw, L. Y. (2015). Digital literacy and effective learning in a blended learning environment. Proceedings of the 14th European Conference on E-Learning, 601-610.

Waycott, J., Bennett, S., Kennedy, G., Dalgarno, B., \& Gray, K. (2010). Digital divides? Student and staff perceptions of information and communication technologies. Computers \& Education, 54(4), 1202-1211. https://doi.org/https://doi.org/10.1016/j.co mpedu.2009.11.006 